\title{
PUBLIC TRANSPORTATION IN SÃO PAULO, BRAZIL: THE DEVELOPMENT OF RAILWAY SYSTEM
}

\author{
Vanessa Meloni Massara ${ }^{1}$ \\ ${ }^{1}$ University of São Paulo, Brazil \\ Received 10 February 2016; accepted 16 September 2016
}

\begin{abstract}
This paper has the main objective, to show the evolution of passenger transport by railway in the metropolitan area of São Paulo (RMSP), with the central point in the capital city, one of the largest cities in the world with over 12 million inhabitants. At first, the Brazilian plan for urban mobility is presented. After, will be discussed the development of railway system in the RMSP and its six lines, focusing the administrative police until the creation of the Paulista Company of Metropolitan Trains (CPTM) and the gradual increase that reached a record of transported passengers: 3,025,185 on December, 2013. Also will be discussed the evolution of built stations as well as the technical characteristics of trains and the improvements through the traction technology. GHG emissions are addressed, making comparisons with others transports. To finalize, the text will be shown future projects of the "Metropolitan Transport Plan" and the conclusions about the service.
\end{abstract}

Keywords: City of São Paulo, CPTM, railway, urban development, urban mobility.

\section{Introduction}

In Brazil, the concern with the improvement and expansion of public transport is growing and is based on the concept of urban mobility. This concept is related to daily movements (travels) of people in urban space (ANTT, 2013).

To have a policy of urban mobility means having a group of principles and guidelines that direct the public actions of urban mobility and the demands of the population.

Affordable tariffs, connection between buses, trains and subways and good sizing fleets are crucial aspects for the perfect access of the population to urban transport and universal access to public transportation, intends the development of cities through sustainable urban mobility (MdC, 2007).

In Brazil, the Ministry of Cities has been working on a national policy for urban mobility, built in conjunction with the various segments of society, which aims to improve the conditions of displacement in the cities for a better quality of life (MdC, 2004).

Federal law n. 12,581, 2012, is a landmark on the concept of mobility and guidelines for transport policies in states and municipalities (ANTT, 2013).

It also highlights the reports: National Policy for Sustainable Urban Mobility (MdC, 2004), PlanMob Notebook (MdC, 2007), and finally, technical report "Passenger

\footnotetext{
${ }^{1}$ Corresponding author: vmmassara@usp.br
} 
trains - A Need it imposes” (ANTT, 2013), dealing specifically the importance of transportation for trains across the country.

\section{The city of São Paulo and the Metropolitan Region}

It is the most populous city in Brazil, with 12 million inhabitants, $1500 \mathrm{~km}^{2}$ and 96 districts divided into many neighborhoods. Around it is the Metropolitan Region of São Paulo (RMSP), also known as Greater São Paulo, which is the largest metropolis of São Paulo and brings together 39 municipalities of the state of São Paulo.

Greater São Paulo is the largest metropolis in Brazil, with approximately 20 million people, and one of the ten most populous metropolitan areas in the World (GESP, 2013a).
To serve this, region the Paulista Company of Metropolitan Trains (CPTM) was founded in 1992 (СРTM, 2012).

It was left for the Company to assume the rail systems of the Metropolitan Region of São Paulo, operated by the Brazilian Company of Urban Trains - CTBU and the Train Paulista S/A - FEPASA. Thus this company received as heritage a railway system of 100 years old and in poor condition, having as main objective the maintenance and renewal of the fleet. (CPTM, 2015).

Figure 1 shows the evolution of building stations, since the first in 1897 . Note that from the 40's, there was intensification in the number of stations but not always corresponding to a good service (CPTM, 2015).

\section{Stations built /period}

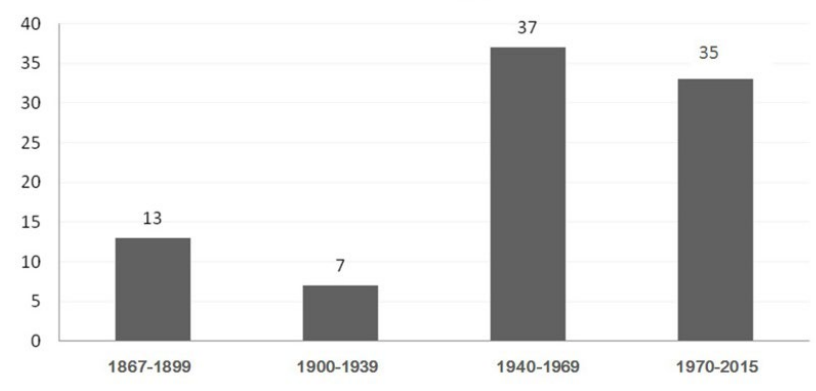

Fig. 1.

Evolution of the Implementation of Train Stations in the Metropolitan Area of São Paulo from 1897 to 2015 Source: Adapted from CPTM (2015)

CPTM carried in the year 2013, 795, 4 million passengers, exceeding by $4.1 \%$ the mark achieved in 2012. There were 2,658 scheduled travels on weekdays with a fleet of 130 trains. The average of passengers carried on a business day was 2.7 million, $4.6 \%$ higher than the previous year. CPTM user travels on average per trip, $19.1 \mathrm{~km}$ and pay a nominal fee of approximately US $\$ 1,12$ (CPTM, 2015).

Figure 2 presents the evolution of passengers demand. The large increase occurred after 2004. 


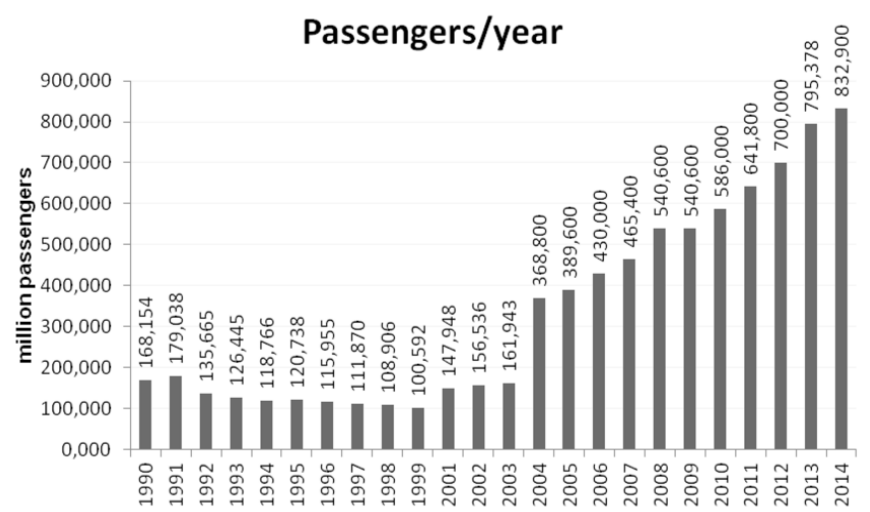

Fig. 2.

Evolution of Demand (1990-2014)

Source: Adapted from CPTM (2015)

CPTM system reached a record of transported passengers: 3,025,185 on December 6, 2013 (CPTM, 2013a).

The systematic increase of passengers, observed in recent years has been possible due to improvements in operational strategies and the receipt of new trains.
However, currently, the capacity of deployed systems is close to its physical limit, not allowing further gains.

On Figure 3 is possible to verify that in a period of analysis of 06 years, transportation by trains has won more followers, with an increase of $62 \%$ (METRÔ, 2013).

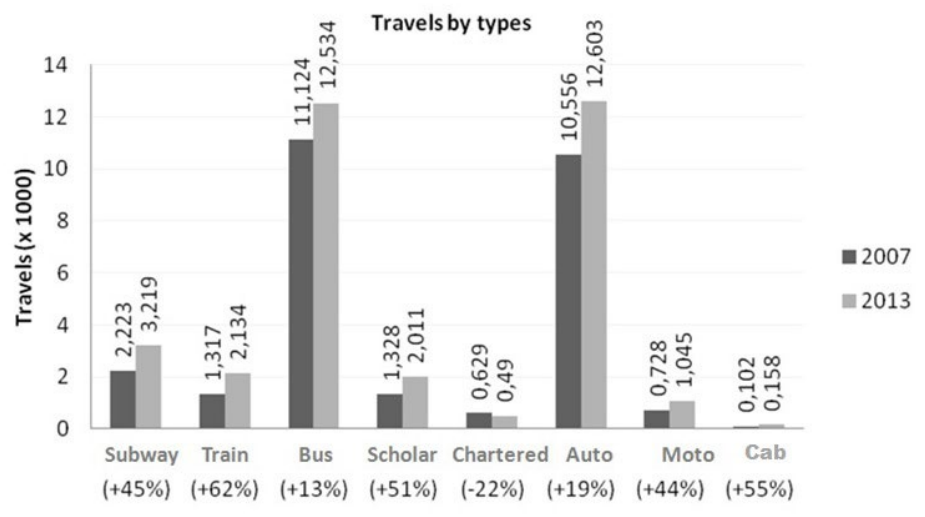

Fig. 3.

Increase in the Type of Transport in the Period 2007-2013

Source: Adapted from Metrô (2013) 


\section{Railway Lines}

At the end of 2015 the company has six lines with its 92 stations, serves 22 municipalities and 3 other municipalities outside the Metropolitan region network: Jundiaí,
Várzea Paulista e Campo Limpo Paulista, totaling $260.8 \mathrm{~km}$.

Table 1 summarizes the principal physical characteristics of the railway lines in São Paulo.

Table 1

Summary of the Routes Characteristics

\begin{tabular}{|l|c|l|l|l|c|l|}
\hline & Line 7 "Rubi" & $\begin{array}{l}\text { Line 8 } \\
\text { "Diamante" }\end{array}$ & $\begin{array}{l}\text { Line } \\
\text { "Esmeralda" }\end{array}$ & $\begin{array}{l}\text { Line } \\
\text { "Turques a" }\end{array}$ & Line 11 "Coral" & $\begin{array}{l}\text { Line } \\
\text { "S afira" }\end{array}$ \\
\hline citie that cross es & 762653 & & & & & $\mathbf{1 2}$ \\
\hline stations1 & 42 & 02 & 01 & 31 & 21 & 3 \\
\hline pass engers/day & 401,573 & 447,285 & 487,133 & 393,822 & 594,612 & 216,815 \\
\hline extension (km) & $38,969 \mathrm{~km} 3$ & 5,2833 & 2,8003 & 4,9605 & 0,8413 & 8,822 \\
\hline conections & 1 with trains & $\begin{array}{c}\text { 1 with trains; } 1 \\
\text { with subway }\end{array}$ & $\begin{array}{l}\text { 3 with trains; 3 } \\
\text { with subways }\end{array}$ & $\begin{array}{l}1 \text { withtrains; } 2 \\
\text { with subways }\end{array}$ & 2 with trains & $\begin{array}{l}3 \text { with trains; } \\
\text { with subways }\end{array}$ \\
\hline
\end{tabular}

Source: Adapted from CPTM $(2012 ; 2013 a ; 2015)$

Note: "Paranapiacaba" at the end of line 10 is a touristic place and isn't considered as station

\subsection{Line 7 "Rubi"}

Line 7 - "Rubi" of CPTM comprises the stretch between stations set "Luz" to Francisco Morato / Extension: Francisco Morato to Jundiaí. Until March 2008, was called The Line - Brown.

The line is considered "one of the early developmental milestones of the city of São Paulo." In the early 20th century, due to the construction of several intermediate stations between the original São Paulo Railway, began the movement of suburban trains, initially until Pirituba. In 1940 the line was electrified, but continued to provide services with wooden cars hauled by locomotives until 1957, when Santos to Jundiaí acquired the first TUEs of the old 101 series (current 1100 series CPTM) (CPTM, 2015).

\subsection{Line 8 "Diamante"}

Line 8 - "Diamante" of CPTM comprises the region defined between Júlio Prestes and Itapevi stations with operating length between Itapevi and Amador Bueno stations. Until March 2008 was called the Line B Grey.

The line would be electrified between 1944 and 1945, a time when the suburban services have reached Amador Bueno. Between the 1950 s and 1960, the line suffered his first reform, having been acquired in 1958 the Kawasaki TEU-Toshiba (current 4800 series CPTM). These trains, however, suffered wear "unusual", and just seven years after the system has already demanded expansion (CPTM, 2012).

\subsection{Line 9 "Esmeralda"}

Line 9 - "Esmeralda" of CPTM comprises the section of metropolitan network defined between Osasco to Grajaú stations. Until October 2007, was called "Line C Celeste", later changing the name to " $\mathrm{C}$ Line - Esmeralda", a name which held until March, 2008. 
The line received twelve new trains of four cars each, which have been in operation since November 2008 In 2010 and 2011 received more trains of eight cars each (sixteen of four cars) due to forecast a large increase in demand with the opening of Line 4 of the São Paulo Metro and the integration between the two lines in the Pinheiros Station, opened in June 2011 (CPTM, 2015).

\subsection{Line 10 "Turquesa"}

Line 10 - "Turquesa" of CPTM comprises the section of metropolitan network defined between stations Brás to Rio Grande da Serra. Until March 2008, was called the Line D - "Bege".

In the early twentieth century, due to the construction of several intermediate stations between the original São Paulo railway, began the movement of suburban trains, initially to Mauá. In the 1940 s, the line would be electrified, but continued to provide services with wooden cars hauled by locomotives until 1957, when Santos to Jundiaí acquired the former Budd TUEs the old 101 series (current 1100 series CPTM) (CPTM, 2012).

With the inauguration of the Vila Prudente and Tamanduateí stations of Line 2 - "Verde" Subway, Line 10 of CPTM served as a handle passengers traveling between the East Zone of São Paulo to the city center with greater convenience, allowing access to Line 3 "Vermelha" Line Subway and CPTM 11 and 12 lines (CPTM, 2015).

\subsection{Line 11 "Coral"}

Line 11 - "Coral" of CPTM comprises the section of metropolitan network defined between the stations of "Luz" and
"Estudantes". It is known as the Eastern Express stretch of the Luz to Guaianases. Currently the most saturated line of São Paulo metropolitan area, also the second most extensive in CPTM. Until March 2008 was called Line E “Orange”. Currently East Express makes 24 trips per day on weekdays and 20 trips per day on weekends to "Estudantes" station in Mogi das Cruzes (CPTM, 2012).

The line started construction in 1869 by the Railway São Paulo to Rio de Janeiro (also known as North Railway), which would be built by the Central Railway of Brazil in 1890. In the early twentieth century began operating suburban trains, initially until the district of Penha, reaching Mogi das Cruzes in the 1910s. This was $49 \mathrm{~km}$ long and passing by nineteen stations (CPTM, 2012).

The electrification of the line occurred only in the mid-1950s. In 1976 the line was extended to the "Estudantes" station, so that it could meet students from colleges located in Mogi das Cruzes. The stretch between "Luz" to Guaianases became known as “Eastern Express” after the World Cup 2014.

\subsection{Line 12 "Safira"}

Line 12 - "Safira" of CPTM comprises the section of metropolitan network defined between stations Brás to Calmon Viana. Until March 2008, was called the F Line - Violet.

The line, known today as "Variant of Poa", "East Variant" or simply "Variant" was built during the 1920s, but it had only been opened in 1934 already offering services to suburban neighborhoods _ considered "rural "in south of "Tietê" river. Over time, Ermelino Matarazzo, São Miguel Paulista, 
Itaim Paulista and Itaquaquecetuba, became densely inhabited localities, mainly lowincome people, which has always been considered as a factor responsible for the fact the online store, to date, the label "the most problematic line of commuter trains in São Paulo" (CPTM, 2013a).

The "Variant" was electrified in the second half of the 1950s, although the suburban trains hauled by steam locomotives had resisted until the year 1963, which increased the fame of precarious line. Already in the 1960s, the line was operating older electrical trains (known 100 series, originating in Rio de Janeiro, manufactured in the 1930s) (CPTM, 2012).

In January, 2008 was inaugurated University of São Paulo - East station, marking the beginning of the modernization and revitalization of Line 12 (CPTM, 2013a).

Figure 4 helps to visualize the coverage of six rail lines currently serving around RMSP.

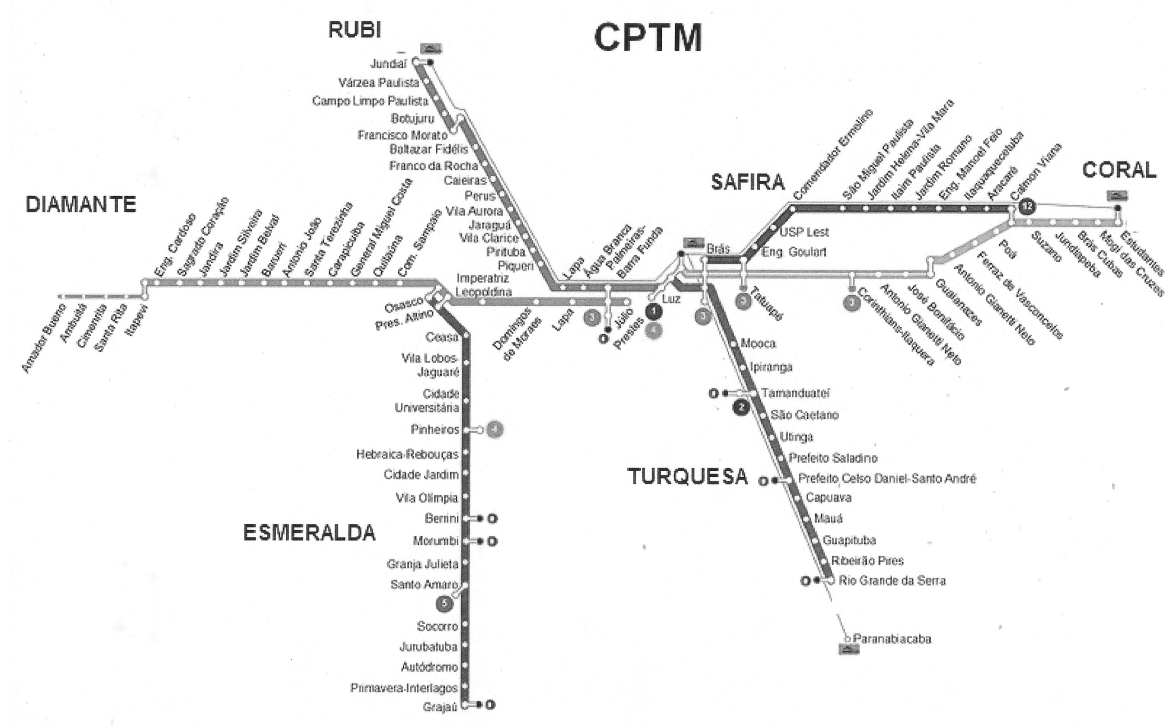

Fig. 4.

CPTM Lines in the Metropolitan Region of São Paulo

Source: Adopted from CPTM (2015) No scale

\section{Characteristics of the Most Used Trains}

CPTM uses models of locomotives ranging from 1100 series to the 9000 series. Figure 5 shows the most widely used series. 


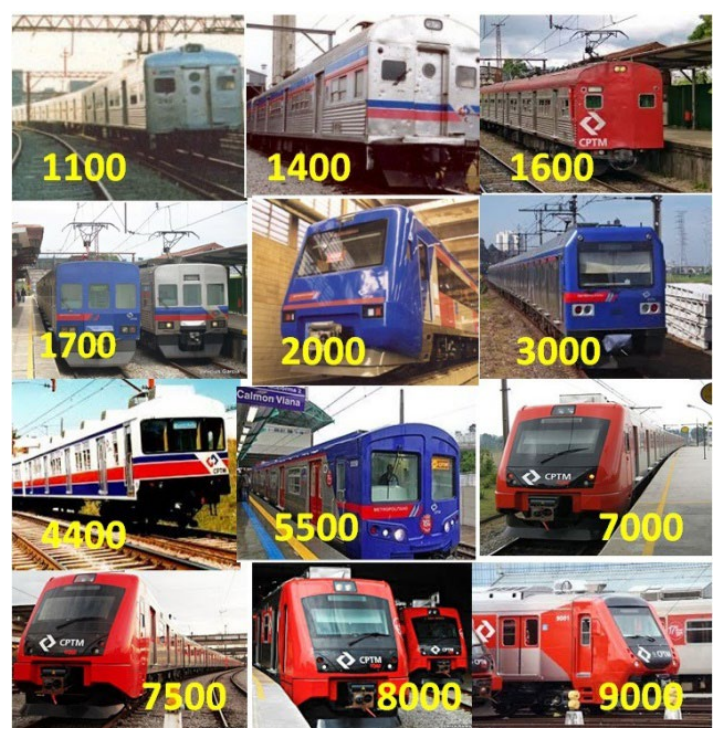

Fig. 5.

Trains of CPTM

Source: Adapted from CPTM $(2012 ; 2013 a ; 2015)$

\subsection{Series (Almost in Disuse)}

1100 series is currently the oldest fleet of CPTM, circulating since 1958. Currently eleven units of six cars each provide fixed services on Line 7 "Ruby” (Luz to Jundiaí).

1400 series came into service between 1976 and 1977, currently, the 17 trains ordered, only four are circulating. All in the extension of Line 7 "Rubi”, with four cars each.

TUE 1600 was acquired in 1978. Now operates in lines 7, 11 and 12 with greatly reduced fleet.

1700 series arrived in Brazil in 1986 by Mafersa. Now left 10 trains used on Line 7 “Rubi” of CPTM (CPTM, 2012).

\subsection{Series}

It was acquired to operate the Eastern Express - line 11.

2070 series was manufactured by companies CAF, Alstom and Bombardier in 2008 and currently operates along the lines 8 and 9 .

2100 series trains were originally manufactured for Renfe - Red Nacional de Ferrocarriles Españoles between 1974 and 1977 by CAF. It arrived in Brazil in 1998 and now is operating in line 10 (CPTM, 2015).

\subsection{Series}

This series was purchased in 1990. In 2011, with the arrival of new trains in CPTM, the 
fleet 3000 was shifted to provide operational support on Line 8 "Diamante" which circulated until recently. Large part is not operating (CPTM, 2012).

\subsection{Series}

4400 series was made in 1965 by companies FNV - National Factory Wagons, Cobrasma - The Brazilian Rail Materials and "Santa Matilde". Now Operates in lines 11 and 12 and is being reformed with characteristics not yet set (CPTM, 2015).

\subsection{Series}

The 5000 currently, operates in line 8.

5500 series was manufactured between the years 1979 and 1980 by Eletrocarro Consortium formed by the companies ACEC - Ateliers Construction Eletriques Charleroi, Sorefame - Societies Reunidas in Mechanical Fabrications, Villares and Mafersa. This series is being reformed with characteristics not yet set (CPTM, 2015).

\subsection{Series}

TUE CAF 7000 series is a train that was manufactured by Construcciones $y$ Auxiliar de Ferrocarriles - CAF at the unit Hortolândia, state of São Paulo and began operations in 2010. Now, this series are divided between lines 8,9 and 11 .

7500 series serves Line 9 "Esmeralda" and at peak times, give support to other trains of series 3000 and 7000 (CPTM, 2015).

\subsection{Series}

TUE CAF 8000 Series is an electric drive train which is being manufactured by
Construcciones y Auxiliar de Ferrocarriles - CAF in Hortolândia, São Paulo, and came into operation in the year 2012. It is the first train to operate with gangway system (free passage between cars). The specifications of this Series were designed to obtain the best performance in terms of reliability, disposition, and maintainability, safety, running costs / maintenance and comfort (CPTM, 2012).

The air conditioning of the passenger lounge and driver's cab with air cooling is now a need to transport passengers because of high heat and high capacity trains during peak hours, which offers better thermal and acoustic comfort.

The audio system is scanned with improved sound communication, automated prerecorded messages for indication of the next station, institutional messages, color monitors for broadcast advertising and music.

The accessibility was facilitated by the installation of devices to implement accessibility of visual communication for closing doors, wheelchair access, number of cars in Braille for the visually impaired, stirrups side to decrease the span and height between the train and the platform and multimedia system (CPTM, 2012).

There are also bright lights for assistance to passengers with hearing disabilities, highlighting to the imminent closing of doors, side and landing indication, insulated gate.

The emergency actuation system allows passengers to alert the driver of any emergency situation that is occurring in the passenger lounge and door for emergency exit. 
The inner lining of modern cars following colors and lines with use of molded fiberglass panels of windows, doors and roof, producing harmonious and pleasant surroundings, reducing the potential for fire using fire resisting material and which does not emanating smoke and toxic gases (CPTM, 2012).

The arrangement of passenger seats is geared to facilitate the flow of loading and unloading, with increased of the open area next to the region of the doors and quality of support columns for passengers, facilitating information, for example, maps with lines, stations and connection with subway.

Sound insulation is designed to keep internal noise level according to the parameters of environmental comfort.

The structure design of the car, both in aluminum or stainless steel is being standardized aims to optimize manufacturing processes, because the parts and pieces that make up the structure of the box are manufactured in modules with door frames, windows, roofing, etc. Thus, gains are obtained also in the development of structural design. Its characteristics are similar to 9000 series (CPTM, 2015; GESP, 2011).

\subsection{Series}

9000 series is manufactured by Alstom and was acquired for expansion of the Eastern Express to the "Suzano" station and was also specified with feature lounge with continuous passages between cars "open wide gangway" (CPTM, 2015).

\subsection{Accessibility for People with Reduced Mobility (PRM)}

In Brazil the Federal Law 10,098 / 2000 lays down general rules and basic criteria for accessibility. In addition, the technical standard NBR 14022/2011 decrees methods for accessibility criteria to be observed in all the fundamentals of public transport system of urban passengers. Both are complemented by Federal Decree 5.296 / 2004 in Section IV - Accessible Public Transport Metro-rail and rail. (GESP, 2013b).

In practice in 2016 from the 92 stations of CPTM, 46 are adapted and 5 are in the works. In line 7 are two adapted stations; on line 8 are ten; on line 9 is eighteen; on line 10 only one; in line 11 are six, and nine in line 12. (CPTM, 2016).

Many stations were modernized, especially those with connections to metro and in the city of São Paulo. (Requeña and Righi 2016). This modernization is directly related to accessibility purposes such as elevators, escalator, ramps, soundcommunication, Braille, telephones for the deaf and for people in wheelchairs, adapted tactile floor and adapted sanitary. At stations as "São Caetano" (line “Turquesa”) there are no ramps or elevators. Thus, wheelchairs are loaded by employees of CPTM or users.

Trains (regardless of series) are $100 \%$ adapted with preferred seating on all lines, visual and sound communication and space for a wheelchair.

The great problem is the exaggerated gaps between the platforms and wagons, ranging 
from 9 to $21 \mathrm{~cm}$ and height, especially in old stations as Lapa, Piqueri and Pirituba (line 7) can reach more than $20 \mathrm{~cm}$. Only the series 8000 and 9000 have lateral stirrups to decrease the gap and height between the platform and the train, which amounts to less than $50 \%$ of trains in use. (Globo, 2016). The goal of CPTM is to reach the level of subway in the city of São Paulo, considered excellent. Other 18 stations have approved project. (CPTM, 2016).

\subsection{Achieved Development}

The new trains purchased by CPTM starting from 1999 were able to operate with intervals between trains of three minutes, when the deployment of signaling latest lines on all systems. The following major improvements adopted by CPTM for new trains (CPTM, 2013a; 2015; Rebelo, 2014):

- Motorization 50\% of cars with traction technology in AC

- Acceleration rate: $0.90 \mathrm{~m} / \mathrm{s}^{2}$

- Fee for service braking: $1.1 \mathrm{~m} / \mathrm{s}^{2}(2000$ series has rate $0.77 \mathrm{~m} / \mathrm{s}^{2}$ )

- Emergency braking rate: $1.2 \mathrm{~m} / \mathrm{s}^{2}(2000$ series has rate $1.1 \mathrm{~m} / \mathrm{s}^{2}$ )

- Air conditioning in the halls of passengers and driving cabs

- Door system with electric motor and detector obstacles

- Automatic passenger information

- Video surveillance system

- Mineral resin flooring

- Data-bus

- Driving and ergonomic cabins with glass panoramic windshield

In addition to these items, the most recent acquisitions also have fire fighting system, monitors for communication with users and system "open wide gangway", which allows users full passage between the train cars.

Another highlight is the modernization of the energy system for Lines. The construction and renovation of the sub-stations are key to achieving the goals of the Expansion Plan because, they enable sufficient energy to ensure that the system behaves increased fleet in circulation and the consequent decrease of the energy range.

Also highlights the implementation of CBTC technology (Communications-Based Train Control), which allows control of distance, speed and amount of brake to be applied in each train in order to obtain the maximum operational performance and the smallest interval between trains operation safely. In addition, the system reduces the use of equipment in railways, which represents lower expenses and higher operational availability (CPTM, 2015).

\subsection{Electric Traction Trains}

In CPTM there are currently 56 trains operating units with this technology and 76 more in manufacturing, which implies that the use of DC motor will be minimum with a tendency of extinction on CPTM fleet (Pereira et al., 2014).

The traction motors used by CPTM are induction type with cage rotor and simpler construction, which makes it more robust and therefore reliable, because is devoid of moving contact elements. Besides these advantages, this type of machine has a better performance than an equivalent DC motor. 
The braking through the electric motors transforms the kinetic energy of the train into electrical energy through the engines, which during this operation become generators. This energy can be returned to the electrical system or dissipated as heat through resistors. This method shows the following advantages:

- Less use of the pneumatic system, saving pads and other brake system components

- Collaborates with the accuracy of train operation, because the braking is controlled by own drive controller

- Energy saving because the energy generated by the train braking can be absorbed by a train that is accelerating or starting in a platform. Another possibility is the return of power to the power utility

- Lower maintenance costs, since the frequency of the maintenance intervention is much higher compared to the DC motor

- Increased reliability because this machine has no moving contacts and the DC motor commutator, which minimizes the chance of a failure

- The control system for this engine can optimize the attractive effort, i.e., the motor will rotate needed to pull the train, reducing "land sliding"

- Provides almost full braking of the train, making the deceleration control be more precise
But there are some factors that we can understand as a disadvantage:

- The high investment for the acquisition of inverters and traction control system

- The complexity of the control technique, which requires specialized technical work

- The major improvement with the use of electric traction is the immense reduction of greenhouse gas emissions (CPTM, 2013b; 2015)

\section{Emissions of Greenhouse Gases}

Social and environmental gains from the high utilization of CPTM, transport that uses cleaner energy shows those investments in the system, can be amortized with the decrease of externalities generated by transport, in metropolitan areas like São Paulo (CPTM, 2015; METRÔ, 2013).

The results of the inventory of greenhouse gas emissions by CPTM showed that the subway transportation emits about 22 times less greenhouse gases per passenger kilometer than cars and almost 10 times less than the bus, considering its transport capacity and the energy used for traction trains (CPTM, 2015).

Figure 6 compares the emissions between types of transport. The train still loses to the subway due to still use diesel oil in part of its fleet. 


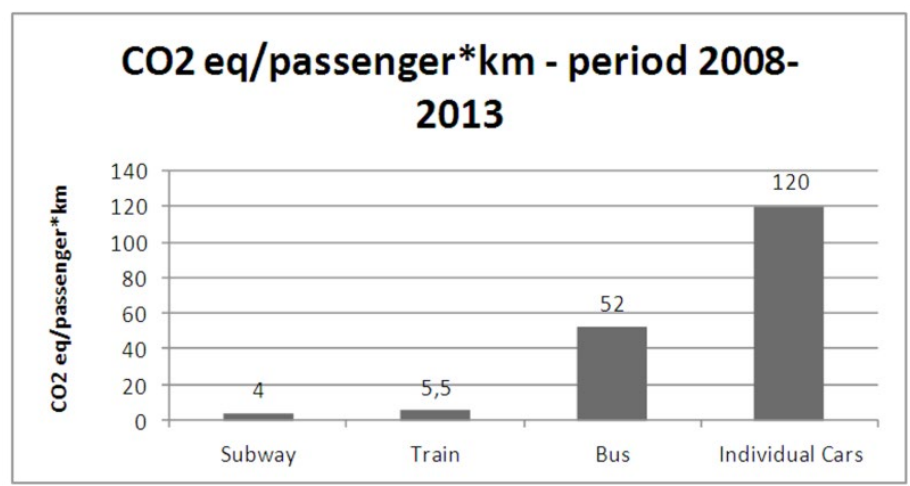

Fig 6.

Comparative Emissions of $\mathrm{CO}_{2}$ eq by passengers/ $\mathrm{km}$ among Various Transport Types Source: (GESP, 2013a; CPTM, 2015; CETESB, 2008)

For the estimates presented, the data used were the fuel consumption in the state of São Paulo, noting that the CPTM uses only diesel oil (fuel oil wasn't used since 2000).

Emissions from locomotives by electric traction are derived from the emissions of electricity and aren't estimated by transportation sector, according to the Energy Balance of the State of São Paulo (GESP, 2013a).

\section{Determinants of the Services Improvements}

Since the 70s, several transport, mobility and master plans discussed the expansion of urban rail transport system. These goals were specifically put into practice from the 90 s and in the XXI century showed significant benefits to users (CPTM, 2012; 2013a; 2015; Haddad et al., 2015):

- Facilitating the connection between employment and housing in various municipalities of the metropolitan area, minimizing distances and travel time
- Modernize and manage trains, tracks and stations

- Greater security for women in wagons

- Shorter interval between trains (5-8 min)

- Increased speed of trains

- Increased signaling and adaptation for the elderly and disabled

- Tariff integration: subway - train - bus and consequent reduction of tariffs

- Integration of transport: subway - Bus terminals - trains

- Greater control over street vendors within the wagons

- Air conditioning, ambient music and cleaning the wagons every travel

- Change of fuel oil for diesel and diesel to electric traction with technical advantages especially in braking and emissions

- $\quad$ Significant reduction in GHG emissions by the use of electric traction

- Real gains in emissions avoided allowing greater investment in the network

Figure 7 summarizes investments in the period 2000-2009, including expansion projects, maintenance and safety of the lines. CPTM is a state company. 


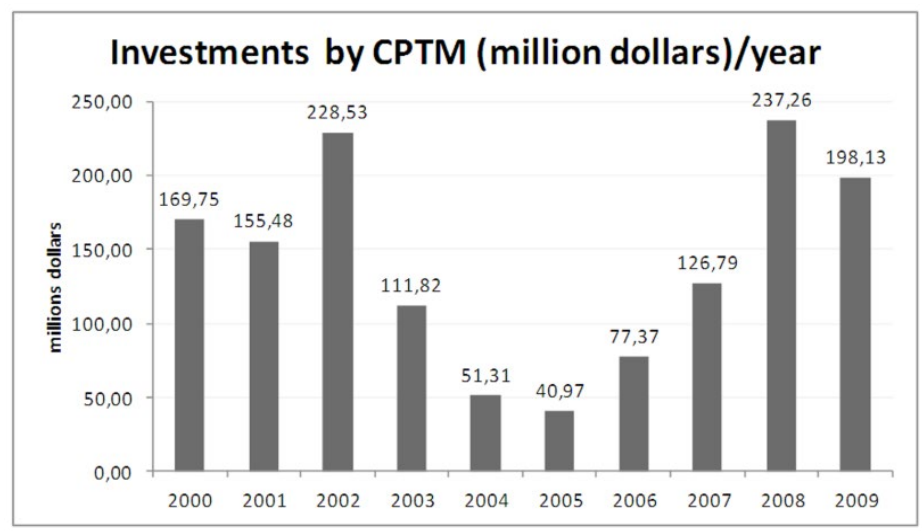

Fig 7.

Investments in Railway System (period 2000-2009)

Source: Adapted from CPTM (2015)

\section{Future Projects of CPTM}

The principal projects underway are (CPTM, 2013a; 2015; Ribeiro Filho and Machado, 2013):

- Over $23 \mathrm{~km}$ of lines by 2016/17

- Over $250 \mathrm{~km}$ of lines refer to the implementation of regional trains, initially linking the capital with Jundiai, Sorocaba and Santos (other cities of São Paulo, outside the capital and metropolitan area), beginning the process of expansion of these services in terms of achieving in the long term of rail passengers in long distance $(2,500 \mathrm{~km})$

- 7 new trains of eight cars, being 68000 series (Public Private Partnership of Line 8 "Diamond") and one train 7500 Series

- Manufacture of 65 new trains 8 cars

- Construction of the new Line 13 - Jade (Train from Guarulhos Airport) and the extension of Line 9; new stations on Line 7 and Line 12
- Adaptation for people with reduced mobility of all stations

\section{Conclusions}

Since the 60s there was an incentive for the automotive industry and for road transport and, over the decades access to private transport has increased given the own car acquisition facilities, which on one hand is good, showing higher capacity income of the lower classes.

In recent years, major congestion and the sustainable development policy have been collaborating for, that part of the population accepted using public transport, especially train and subway, with significant gains as were showed at the beginning of this chapter.

But the connection between subway and train increased passenger numbers at peak times, which is still a downside given the "congestion of people" in working and school hours, and this makes difficult to change the perception of the use of individual to the collective transport. 
So, even with many improvements in the service of CPTM, are necessary the constant expansion and maintenance of services. But undoubtedly, train will be in the coming years, one, or maybe, the best alternative in the public transport of São Paulo.

\section{References}

ANTT. 2013. Passenger trains: a necessity that imposes itself (in Portuguese: Trens de passageiros: uma necessidade que se impõe). Agência Nacional de Transportes Terrestres - ANTT, Brasil. 52p.

MdC. 2007. Book PlanMob: for guidance to municipal governing in the preparation of Urban Mobility Plans (in Portuguese: Caderno PlanMob: para orientação aos órgãos gestores municipais na elaboração dos Planos Diretores de Mobilidade Urbana). Ministério das Cidades, Brasil. $60 \mathrm{p}$.

MdC. 2004. National Policy for Sustainable Urban Mobility: Principles and Guidelines (in Portuguese: Política Nacional de Mobilidade Urbana Sustentável: Princípios e Diretrizes). Ministério das Cidades, Brasil. 145p.

CETESB. 2008. 1st Reference Report of São Paulo Anthropogenic Emissions of Greenhouse Gases, period of 1990 2008 (in Portuguese: $1^{\circ}$ Relatório de Referência do Estado de São Paulo de Emissões e Remoções Antrópicas de Gases de Efeito Estufa, período de 1990 - 2008). Companhia Ambiental do Estado de São Paulo - CETESB, Brasil. 47p.

CPTM. 2012. Management Report 2012 (in Portuguese: Relatório da Administração 2012). Companhia Paulista de Trens Metropolitanos - CPTM, Brasil. 198p.

CPTM. 2013a. Management Report 2013 (in Portuguese: Relatório da Administração 2013). Companhia Paulista de Trens Metropolitanos - CPTM, Brasil. 172p.
CPTM. 2013b. Traction motors in AC: Performance Study on CPTM (in Portuguese: Motores de tração em corrente alternada: Estudo do desempenho na CPTM). Companhia Paulista de Trens Metropolitanos - CPTM, Brasil. 14p.

CPTM. 2015. Management Report 2015 (in Portuguese: Relatório da Administração 2015). Companhia Paulista de Trens Metropolitanos - CPTM, Brasil, 260p.

CPTM. 2016. CPTM works to adapt its dependences to current accessibility Standards (in Portuguese: A CPTM trabalha para adequar suas dependências às normas vigentes de acessibilidade). Companhia Paulista de Trens Metropolitanos - CPTM, Brasil, 11p.

GESP. 2011. Public Hearing on trains maintenance of CPTM (in Portuguese: Audiência Pública sobre manutenção de trens da CPTM). Governo do Estado de São Paulo - GESP, Brasil. 45p.

GESP. 2013a. Energy balance of the state of São Paulo 2013 - Year: 2012 (in Portuguese: Balanço Energético do Estado de São Paulo-Ano-Base: 2012). Governo do Estado de São Paulo-GESP, Brasil, 294p.

GESP. 2013b. Accessibility Guide for metropolitan transport (in Portuguese: Guia de acessibilidade nos transportes metropolitanos). Governo do Estado de São Paulo - GESP, Brasil, 10p.

Globo. 2016. Lack of accessibility hinders passengers of CPTM in Alto Tiete (in Portuguese: Falta de acessibilidade atrapalha passageiros da CPTMno Alto Tietê.Mogi das Cruzese Suzano). G1 - Tv Diário - Globo.com, Brasil, 4p.

Haddad, E.A.; Hewings, G.J.; Porsse, A.A.; Van Leeuwen, E.S.; Vieira, R.S. 2015. The underground economy: Tracking the higher-order economic impacts of the São Paulo Subway System, Transportation Research Part A: Policy and Practice, 73: 18-30. 
METRÔ. 2013. Mobility Search of metropolitan area of São Paulo (in Portuguese: Pesquisa de Mobilidade da região Metropolitana de São Paulo). Metrô, São Paulo. 183p.

Rebelo, J.M. 2014. São Paulo and Mumbai: the impact of rail based networks on two bric mega cities. Google Book. 63p.

Requeña, C.A.; Righi, R. 2016. Revitalization of railway lines 9 and 10 of the CPTM, in São Paulo, Brazil, Journal of Multidisciplinary Engineering Science and Technology, 3(3): 4381-4385.
Ribeiro Filho, E.B.; Machado, M. 2013. Renewal of train fleet elevates level of comfort (in Portuguese: Renovação da frota de trens eleva padrão de conforto), Revista Brasil Engenharia, 613: 86-89.

Pereira, F.H.; Pires, C.L.; Nabeta, S.I. 2014. Optimal placement of rectifier substations on DC traction systems, IET Electrical Systems in Transportation, 4(3): 62-69. 